Modern Asian Studies 33, 2 (1999), pp. 303-338. (C) 1999 Cambridge University Press Printed in the United Kingdom

\title{
Colonial and Contemporary Ideologies of 'Community Management': The Case of Tank Irrigation Development in South India
}

\author{
DAVID MOSSE
}

School of Oriental and African Studies, London

\begin{abstract}
This is an essay in the sociology of knowledge. It aims to demonstrate, firstly, how development institutions construct rural society in terms of organizational imperatives, and secondly, how these 'constructions' come to be underpinned by social theory. The focus is on irrigation in south India and colonial and contemporary state policy initiatives to promote local institutions for the community management of decentralized resource systems. The essay presents the social and historical origin of an important and powerful set of contemporary policy ideas. The significance of this lies in the continuing misperception of local institutions of resource management, and in particular the systematic isolation of resource management from its particular social and historical context.
\end{abstract}

\section{Introduction}

This paper concerns the ideology and practice of 'community management' in the planned development of common property

\footnotetext{
${ }^{1}$ This paper is a spin-off from some more detailed historical and anthropological work in progress. It is a preliminary exploration of the relationship between development ideas and institutions which will, no doubt, be qualified or substantiated by evidence from further field and archival work. The research on which the paper draws is supported by a Fellowship from the Economic and Social Research Council under the Global Environmental Change Programme (Grant No. L320273065) and by a grant from the Ford Foundation (New Delhi). I am grateful to the Centre for Water Resources (Anna University, Madras), the Madras Institute of Development Studies and the NGO Pradan (Madurai) for their support. An extended version of this paper was presented at the International Conference on The Political Economy of Water oo26-749X/99/\$7.5 ${ }^{\text {O+ } \$ \text { o.1 o }}$
} 
resources. Specifically, it deals with ideas about village institutions of minor irrigation management in Tamil Nadu and interventions with which they are associated. Although focal to recent thinking on common property development, these ideas have a history which stretches back to the initial days of colonial rule in the early $19^{\text {th }}$ century. There are some striking continuities over this long period. Underlying these is the perhaps well-known tendency of agenciescolonial governments or development projects-to conceive of rural society in terms which are appropriate to given programme and administrative systems. In particular, ideologies of village organization have long served a bureaucratic need to simplify and universalize local social systems, most broadly, 'to organise the mass, to change an undifferentiated and unreliable citizenry into a structured, readily accessible public' (Selznick 1949, cited in Robertson 1984: 140).

Obviously over time, the social theory employed has changed. The colonial government in India formalized, generalized and (as I shall argue) in some respects invented the 'custom' and 'tradition' of village communities as a basis for minor irrigation administration. Contemporary irrigation management practice while inheriting many notions of community tradition, employs its own generalizing models which (often drawing on institutional theory) emphasize local irrigation institutions as self-managed organizational solutions to problems of task fulfilment and the distribution of material benefits (cf., Uphoff 1986, Curtis 1991, Ostrom 1990, 1992). In this paper I shall argue that the legitimate need to generalize 'design principles' for farmer-controlled irrigation here, no less than the colonial administration's use of 'custom', involves an institutional isolation of resource management from its particular historical and social context, and in doing so overlooks the importance of political relations and the cultural construction of natural resources.

Among the more influential ideas shaping rural development interventions today is the notion that, if given unambiguous and secure rights of access and use, communities are better managers of the natural resources upon which they depend for their livelihoods than are state bureaucracies. This argument is increasingly applied to non-private environmental resources such as forests, grazing land 
or irrigation water, whose degradation centralized resource management systems have appeared powerless to control. Many programmes in these sectors are therefore working towards 'joint' or 'community' management regimes in which the state machinery (departments of forestry, public works, etc.) transfers resource management responsibilities to local farmers (e.g., IIMI \& WUHEE 1994; Poffenberger 1990). It is the construction of community in the context of policies of resource management transfer which is the subject of this paper.

While communities are considered as likely to be better managers of local resources, an underlying and equally influential contemporary policy idea is that present levels of resource degradation are in significant measure the result of the 'dissolution of traditional institutional arrangements' for sustainable resource use (Bromley \& Cernea 1989:iii). In some recent analyses, intervention by the state (and particularly the colonial state's assertion of proprietary rights over non-private resources, such as water and forests) is seen as the principal cause of the demise of traditional systems of sustainable resource use (e.g., Gadgil \& Guha 1992). But, even if the state is not viewed as directly responsible for this dissolution, it is often held that national governments have failed to substitute for indigenous resource management regimes (Bromley \& Cernea 1989:iii), the demise of which has led to the damaging shift towards uncontrolled 'open access' to non-private resources. The policy solution to this problem involves the (re-) establishment of local users' rights and the building up of 'forms of social organization conducive to sustainable productive use of natural resources' (ibid. iv). This usually translates into programmes of local 'institution building' and the promotion of special purpose local organizations: village water users' associations, forest protection committees and the like. Linked to the idea of the dissolution of traditional systems, these programmes are, not uncommonly, built around the powerful ideology of recovery of 'traditional' community institutions of resource management.

The focus of this paper is on 'tank' irrigation systems in Tamil Nadu, and state (and latterly NGO) programmes for their restoration. Through this example, I will examine the history of ideas of 'community management', and show that contemporary concern with the dissolution of traditional tank management systems, and ideas of community management, farmer control and management transfer more generally, are not recent but are rooted and have their origin in the exigencies of colonial administration in the nineteenth 
century. I will then suggest that today's development agencies also selectively endorse particular social theories in constructing a rural society which is manageable in terms of present policy goals and administrative constraints. ${ }^{2}$ I want to make it quite clear, however, at the outset, that my argument is not about the merits or otherwise of policies of irrigation management transfer or local institutional development. (I do happen to believe that in many ways these offer the best-perhaps only-hope for improving water resources management). Neither is my argument to be read as an evaluation of the contribution of economic-institutional theories of collective action. Rather, my concern with the relationship between organizational interests and social theory within colonial and contemporary policy discourse and with the selective representations of rural society which this generates.

\section{Tank Systems and Decline}

A tank is a manmade reservoir created by a simple earthen construction (the 'bund') that captures surface run-off. Water is distributed to fields below the tank by gravity flow through a variable number of sluices. The nature of drainage often links individual tanks into local 'chains', and to perennial or temporary rivers and streams (Mosse 1997a, 1977c). The broader concept of the 'tank system' includes these wider linkages as well as the relationship of tanks to catchment areas, and to groundwater supply. Tanks therefore have a range of functions beyond irrigation (percolation and groundwater recharge, flood control, silt capture etc.) and are affected by changes in the wider resources 'complex', including changes in land use, cropping patterns etc. (Ambler 1992). By any reckoning, the very large number of tanks in Tamil Nadu (around 39,ooo) have, in recent years, declined in importance in both relative and absolute terms. The expansion of canal, but especially well irrigation (in the $1960 \mathrm{~s}$ and 7os) has shifted tanks from the position they occupied, even in the early 1970 , as the single largest mode of irrigation in the state. But there has also been a long-term decline in the area under tank irrigation in absolute terms. In all districts many tanks are physically

\footnotetext{
${ }^{2}$ Elsewhere I have shown how the development discourse of community can also legitimize new claims on resources by disadvantaged groups (Mosse 1997b, cf. Li 1996).
} 
in disrepair, they are silted up, encroached upon, their sluices are inoperable, and bunds and weirs are damaged (see MIDs 1986, Vaidyanathan 1992).

The reasons for tank decline are complex and historically specific. Adequate treatment of them is well beyond the scope of the present paper. They include factors associated with deforestation (from the late 18 th century), decline in the reliability of water supply, population growth, intensified land use and crop regimes, siltation and encroachment onto tank beds, colonial revenue systems which penalized investment in paddy land, an increase in individualized water control through the use of private wells and the inadequacy of state investments. ${ }^{3}$ However, a particularly pervasive diagnosis of the problem in official circles, as well as among observers, has long been that a 'traditional' system of resource mobilisation, maintenance and repair has collapsed, and that traditions and skills have been lost. Such analysis points in particular to the 'erosion of the autonomous functioning of village management systems' (Vani 1992:9, emphasis added).

This is not, however, a new observation. It is true that today, underlying tank development programmes, there is a notion that the history of tank decline is the history of the incursion of the colonial state into traditional village institutions, but early 19th century English East India Company officers saw decaying village tank systems as sign of the administrative and moral disorder of the regimes which they had come to replace. Tank systems have, in fact, been interpreted as being in a state of decline, neglect and disrepair wherever they have been described. The historical identification of 'traditional' village systems and the moment of their collapse is no simple task. It involves a seemingly endless journey back in time. Thus, the decisive moment of loss is variously located in: the present government's neglect of indigenous knowledge and traditions, in the 1960 -70s green revolution expansion of capitalist agriculture and groundwater irrigation; in changes brought about in the $195^{\mathrm{O}}$ following Independence (e.g. the abolition of Zamindari estates and the establishment of structures of local government); in the colonial commercialization of dry land agriculture in the late $19^{\text {th }}$ and early 2oth centuries; in the centralization of colonial government and the

\footnotetext{
${ }^{3}$ See discussions in: Djurfeldt and Lindberg 1975; Elumalai 1982; Harriss 1982; Granda 1984:354; Ludden 1985, 1979; Meinzen-Dick 1984, 1989; Vaidyanathan 1992; Mukundan 1988; Palanisami 1981; Palanisami and Easter 1984:29; Palanisami et al. 1994; Rajanam Rao 1891; Sivanappan 1982.
} 
building of a technocratic irrigation bureaucracy from $185^{\circ}$; in the consolidation of British power, its revenue systems and property law by the 1840 ; in the dismantling of the south Indian 'old regimes' around 1800 ; in the wars of the immediate pre-colonial period of the 179os; in the neglect of decentralized systems under Mohammedan rule during the 18 th century; in the disruption generated by the rise of the Vijayanagar empire in south India after 1350; in the collapse of the 1oth century Chola empire and its system of locality and village government, and so it goes on. ${ }^{4}$ Tracing 'traditional' tank systems is strongly reminiscent of Raymond Williams' literary pursuit of the old order of rural England-an exercise which he likened to stepping onto a backward moving escalator: the timeless rural community is always just over the last hill (Williams 1973, discussed in Spencer 1990:140). Like the ideal rural order of which they are a part, tank systems never simply change, they decay (ibid.). Indeed, a pervasive image is one in which social and political forces acting on tank complexes do not constitute, underpin, reproduce or extend these systems, they simply erode, dissolve or undermine them. The point is that village tank management systems and their decline are not so much historical as ideological phenomena. Further, as ideologies of community management, traditional tank institutions are constructed in historically specific ways and have provided legitimizing charters for different development regimes.

\section{Kudimaramat: 'Villager Repairs' and the Colonial Construction of Community Management}

The idea of autonomous village irrigation management or maintenance systems, in one form or another, has provided a key element in tank development policy in south India for over a hundred years. The reason is, not least, because of the insurmountable administrative problems and financial burden government faces in the work of maintaining tens of thousands of tanks which, as one 19th century British engineer commented, is 'at once too large in the aggregate, too small in detail-as well in fact [as to] attempt to keep every hut

\footnotetext{
${ }^{4}$ These various interpretations come from a very large number of sources. Among some of the more recent are Djurfeldt and Lindberg 1977; Palanísami and Easter 1983, Ludden 1985, Vani 1992, Harriss 1982, Granda 1984, Sarada Raju 1941 .
} 
in the country in repair'. ${ }^{5}$ The colonial government of the time needed 'traditional' autonomous village tank institutions for its public works administration, just as it needed 'traditional' village headmen for the organization of its revenue system. Where these appeared no longer to exist they had to be re-invented. Indeed, the Madras Public Works Commission of 1869-70, and successive commissions of enquiry during the remainder of the 19th century went to considerable lengths to amass evidence to prove the existence of village institutions of tank maintenance and communal labour, generally referred to as kudimaramat, 'villager repair or maintenance works'. ${ }^{6}$ This effort was prompted by a growing perception (supported by reports from the districts) that a large proportion of tanks in many regions were in a state of disrepair, and that the burden of their repair could no longer be ignored by the government in favour of investment in the more productive larger irrigation works (cf. Mukundan 1988:12). Not only did the failure of minor irrigation systems represent a loss of revenue, but, in the 1870 os and 8 os, it contributed to an environmental crisis which had played its part in generating famine on a massive scale. In the Commission reporting on Famine of $1877-78$, which cost an estimated 1.35 million lives in Madras and Mysore, the colonial government admitted for the first time its moral obligation to maintain minor irrigation. Government not only increased its sponsorship of tank repair, but also insisted on its overriding right to own and control local water resources in the public interest-hence the origin of irrigation law in Madras. By this time also the Ryotwari revenue settlement had turned irrigation commons into state property (cf. Sengupta 1995:7). As the state bureaucratized irrigation administration and extended its own proprietorial right over water resources-and as a new centralized and technically specialized Public Works Department (PWD) gained ascendancy over the decentralized and generalist Revenue Department in tank matters-the Madras government's

\footnotetext{
${ }^{5}$ A statement made in 1868 by Maj. R.H. Sankey, then Chief Engineer in Mysore State, cited in Vani 1992:89.

${ }_{6}$ The term kudimaramat is a composite of the Tamil kuti-'inhabitant', 'subject', and the Arabic maramat-'repairs'. It appears in the records only after the 1860 , and remains, even today, largely unknown in rural areas. Deliberations on kudimaramat occupied the major Commissions on Public Works (1869-70), Famine (1880) and Irrigation (1901-03) and filled the proceedings of the Board of Revenue and Public Works for over thirty years. They are reviewed and analysed in a book in preparation (Mosse, in preparation). There were comparable colonial debates in north Indian canal irrigation maintenance (Gilmartin 1994: 1134, 1137).
} 
efforts to constitute 'customary' village institutions as the basis for local resource management also increased. ${ }^{7}$

State programmes of tank repair and improvement, such as the Tank Restoration Scheme (TRS) started in 1883 and continued until very recently, were firmly premised upon villager maintenance and upkeep of smaller tanks (the majority, irrigating under 200 acres) 'according to the old custom of the country known as kudi-maramat, ${ }^{8}$ and the transfer of tanks to villagers for management. Despite increasing reports of the collapse of kudimaramat-especially from the more precarious areas of rainfed tanks - the members of the 1901o3 Irrigation Commission were 'reluctant to admit that so valuable an institution is really dead and past restoration'.

The colonial government did not, as is often supposed, take over and undermine an institution (kudimaramat) belonging to the people. Rather the PWD and the Madras government defined, ordered, generalized, in short, invented a village tradition in the image of the state's planned irrigation administration. The problem was not the nineteenth century colonial erosion of irrigation tradition so much as its invention as a solution to the administrative demands which a decentralized resource system placed on an increasingly centralized state. Indeed, for tank systems, 'traditional' community management was the corollary of state power not its inverse.

\footnotetext{
${ }^{7}$ I overlook, here, significant differences within British government administration, notably between the decentralized Revenue administration and the new centralized technical departments of Public Works, Forestry and so forth, formed in the late nineteenth century. David Gilmartin (1994), for example, brings out a sharp contrast between, on the one hand, the social scientific discourse of early revenue settlement officers, which incorporated idioms of custom and genealogy into a new legal and administrative language of the colonial state-the 'science of empire'and, on the other, the ascendant technical, universal discourse of irrigation science- 'imperial science'. In Madras, too, the 'imperial science' of the Public Works Department displaced a 'local knowledge' including the set of 'rights and customs' through which local revenue administration operated. Indeed, the Madras PWD was founded upon a rejection of the sort of local authority, rights and privileges into which revenue administration was moulded, and the establishment of a scientific administration based upon principles of technical efficiency. However, by the 1870 , the PWD was forced to confront insuperable problems and costs associated with its attempt to impose 'imperial science' onto decentralized tank systems (as against large canal systems), and with its disregard of the earlier nexus linking local rights and privileges to colonial administration. In fact, as argued here, from the 1870 , the PWD took the lead in reinventing 'community', but now in terms of a centralized technical administrative system rather that the earlier revenue system.

${ }^{8}$ Report of the Indian Famine Commission, Part II, 'Measures of Protection and Prevention'. Parliamentary Papers Vol. L1 1, 1880 (India Office Library).

${ }^{9}$ Report of the Indian Irrigation Commission (I9OI-O3), Part II, Provincial, p. 112.
} 
The manner in which kudimaramat was 're-created' as a traditional autonomous village institution provides an illustrative case of the way in which (at least by the late nineteenth century) the 'autonomous village community' was constituted as the basis for colonial administration more generally (Ludden 1993); and the way in which rural society was ordered, reified, statistically recorded, administratively controlled and fundamentally changed. Through its commissions and reports, the government became the repository of authoritative and empirical knowledge on local irrigation custom and practice (ibid.). While reports from the districts evidenced a wide diversity of local practice and officers' opinion on systems of tank maintenance, it was central definitions which determined policy. Indeed, despite appearances, the bureaucratic notion of kudimaramat was, in fact, quite independent of the actual record of village-level social systems of tank management. But then, these were never really examined in themselves anyway (Sengupta 1985:1933). Rather, kudimaramat notions derived exclusively from observations on the physical consequences of custom or, more usually, its absence-i.e., tank disrepair. From 1882 a large establishment was set up to survey tanks and produce on them a centralized and uniform set of records as the basis for state involvement. These surveys defined (and continue to define) tanks as physical systems and specified for each an engineering 'standard of efficiency'. This record, at the same time, determined an officially approved standard for 'customary' community systems of maintenance: that custom which must have existed to operate the system efficiently. 'The term kudimaramat', wrote the Board of Revenue in 1876 , 'shall be held to include all the works ... enumerated in the Board's Standing Order No. 54'-a fixed list of customary tank maintenance practice. ${ }^{10}$ Guided by this standard, an empirical and official record of villagers' customary obligation for tank maintenance in each village - the Kudimaramat Dittum-was to form part of the official records of a village and would provide an authoritative guide in cases of dispute. ${ }^{11}$

The kudimaramat tradition of official discourse was constructed so as to satisfy two administrative imperatives. Firstly, diverse local irrigation maintenance practice was empirically 'fixed' and rendered as a generalized standard, and this was set by engineering standards

${ }^{10}$ Proceedings of the Board of Revenue No. 1192, 6 May 1876 (Tamil Nadu State Archives, Madras).

11 'Bill for the Enforcement of Kudimaramat in the Presidency of Madras', Appendix E. Public Works Commission 1870 (Tamil Nadu State Archives). 
of efficiency. Secondly, the government's demands on villager labour, resources and management acquired the legitimacy of custom. The extension of state power which lay behind this regimentation of 'local knowledge' (Ludden 1992) and invention of tradition was hardly disguised. The codification of community obligations served as a means to extend central government control of tank resources by ensuring a new (as we shall see legal) accountability of villagers to government (Vani 1992:55). ${ }^{12}$

As an invented village tradition, however, kudimaramat was in dissolution from the moment it came into being (compare Mayer 1993:386). The bureaucratically constituted kudimaramat set a published and approved 'standard' against which enough cases of local practice failed to measure up for the notion of the collapse of local custom - that kudimaramat was in decline or had ceased to existto gain wide currency. ${ }^{13}$ Perceiving a collapse of customary obligations, the government turned to law. The Commissioners on Public Works, Irrigation and Famine and the Board of Revenue, were all convinced of the expediency of legislation 'to give permanence to existing organisations ... [where the system of 'kudimaramat' is already in force] and of reviving it where it has fallen into deseutude'. ${ }^{14}$ Indeed, more than anything else kudimaramat became a concept of legal obligation bound by the nineteenth century British judicial 'norm of universal applicability' (Price 1991:117). Beginning with the Madras Compulsory Labour Act (1858) (known as the Kudimaramat Act) government took a series of steps to enforce community maintenance of tanks and customary labour by law. ${ }^{15}$ Several

12 The central bureaucratic invention of tradition, here, is to be distinguished from the earlier 'social scientific discourse' which underpinned British revenue settlement and administration in the early nineteenth century (cf. Gilmartin 1994). Through the latter, revenue officials explicitly recognized (or established) local rights and authority in tank systems. Kudimaramat was a quite different 'tradition', which in fact, met with much opposition from district revenue officers (Mosse, in preparation).

${ }^{13}$ There may have been other reasons for this also. Through farmer petitions, government attention was likely to have been disproportionately drawn to those tanks which needed repair and in which maintenance systems had failed (Sengupta 1991); and where, in consequence, government engineers would have experienced problems in generating community involvement and mobilising unpaid labour.

${ }_{14}$ Proceedings of the Board of Revenue No. 1, 192, 6 May 1876.

15 The government was undecided as to whether kudimaramat was essentially a system of voluntary or forced labour (Matthai 1915:9-125), although the Compulsory Labour Act of $185^{8}$ undoubtedly put into place the practice of corvee labour (Ambler 1993:4). This coercion of labour in public works was at times justified with reference to traditional village or high caste rights over untouchable labour (Ludden 
Kudimaramat Bills were drafted $(1869,1883)$ to underwrite custom with the force of law. Not surprisingly, the Act failed and the bill was dropped because enforcement of the law depended upon the impossible task of proving in court that kudimaramat was customary practice in any particular village.

Community involvement in irrigation management as a 'development' policy idea, therefore, had its origins in the organisational problem which tank systems presented to an increasingly centralized public works bureaucracy in the second half on the 19th century. Kudimaramat (i.e., generalized custom backed by law) was not a descriptive category of village-level collective action but an ideological instrument enabling the assertion of state control (over water), while delimiting state obligations. This was required, particularly after the $185^{\text {os }}$, as the government of Madras defined for itself a new and bureaucratic independence from older networks of local power and authority of the pre-colonial regimes through which an earlier generation of East India Company revenue officers had operated. With this disengagement from local political structures, the newly centralized government (represented locally by PWD engineers) experienced the failure of its own authority over tank maintenance, and the loss of its earlier ability to command labour for tank repair works.

The picture of kudimaramat as an invented tradition is consistent wth some recent historical analyses which suggest a reversal of earlier perceptions. As David Washbrook succinctly puts it, instead of British rule and the forces of Western capitalism eroding the static society of village communities, 'we have moved towards views of a highly mobile and economically-differentiated society rendered stationary and "traditional" by the processes of "peasantisation" implicit in the colonial project' (1993: 68). And as other studies have demonstrated, this 'fixing' of rural society involved an isolation of village 'traditions'-for example those of caste, jajmani, or temple worship-from wider political structures which was, in a more general sense, both a political and an ideological imperative of British rule in India (see Dirks 1987, Ludden 1993, Fuller 1989, Stein 1989, Mayer 1993). Thus, much of 'traditional' village India is now under-

$1985: 174)$. Ironically, the officers 'extrapolated from the village to the government', rights over labour formerly held by dominant land-owning castes, but which had been rendered illegal by anti-slavery legislation (ibid., Mayer 1993:363). 
stood as a product of colonial government which, in rather complex ways, truncated, transformed and reifed the wider set of dynamic political relations of the pre-colonial state which had earlier defined institutions of caste, temple and, I argue, resource management. Colonial constructions of autonomous village-level water management traditions, exemplified by kudimaramat, were also a concomitant of political changes which isolated tank systems from regional political structures, reconceiving them in localized, traditionalized and bureaucratic terms (cf. Washbrook 1988). Despite these insights from historical analysis, 'steady-state' models of rural society continue to hold dominance within contemporary irrigation development discourse (see below).

As I have shown elsewhere there are, in fact, good reasons for believing that pre-colonial tank irrigation systems, certainly in the plains areas where this form of irrigation dominated agriculture, were not resourced, maintained and operated by autonomous village institutions, but by a wider set of political relations of the decentralized, or 'segmentary' (Stein 1980) pre-colonial state (Mosse 1997a, n.d. in preparation). Evidence on these pre-colonial systems of resource management, however, eschews environmental romanticism: they rested on an inequitable social order, were underpinned by political systems which generated conflict, plunder and the destruction of tanks systems (Lardinois 1989:24-5, 38-43), as well as their protection, repair and extension through royal grants, largesse and patronage (Dirks 1987) and did not therefore always ensure investments adequate to keep tanks in order. Nonethless, (and in ways which cannot be detailed here) these political systems generated resource flows and defined authoritative positions, rights and obligations which operated supra-village mechanisms for the construction, maintenance and integration of interlinked tank systems (ibid:: 148). Indeed, investment in and the operation of tank systems was indissolubly linked to legitimate political overlordship, and my own ethnohistorical work (in Sivagangai and Ramnad) establishes a persisting link between systems of caste honour and tank irrigation works in the articulation of authority at the level of village, micro-region and kingdom. ${ }^{16}$

\footnotetext{
${ }^{16}$ The mass of litigation during the $19^{\text {th }}$ and early 20 th century over water rights which erupted in this area (through newly established courts) only underscores the significance of 'higher authority' in establishing local water rights and arbitrating disputes (cf. Ludden 1985:89-90, Mosse 1997a, n.d. in preparation).
} 
This system of 'segmentary' political relations was not suddenly terminated by the arrival in the Tamil countryside of the British (East India Company). Company revenue officials, in fact, 'settled into existing functioning networks of state power and authority' (Ludden 1985:128-9) through which they effected the tank repair necessary to secure continuing revenue flows. Nonetheless, government reforms from the 185 os were highly critical of these accommodations to existing authoritarian structures, and gradually put in place a centralized public works machinery separate from revenue. As Gilmartin puts it, the 'science of empire' gave way to 'imperial science' (see footnote no. 8). The impact of British rule on tank systems is complex and beyond the scope of the present essay. Suffice it to say that the more centralized revenue and administrative systems initiated by its Mogul predecessors, but finally put into place by Company raj (Washbrook 1988, Stein 1985), gradually dissolved segmentary political relations, and broke up earlier resource flows and the 'existing circuit of investment and social reproduction which had long obtained under pre-colonial regimes' (Stein 1985:412). On the one hand 'honours and local position could no longer be secured through the integrated relation of community benefaction and patronage, [and instead] local magnates began to invest ... in new economic opportunities afforded by colonial trade'. (Dirks 1987:357, emphasis added); and on the other hand, as Washbrook argues, authority and social position no longer required such benefaction. In other words, British rule, in various ways, emancipated local political chiefs and big men from the obligation to invest in community resources and public institutions such as tank systems (Washbrook 1976:332, 1988:92). The shortfall was not made good by the government's own public works.

If tank systems declined under colonial rule, then, it was the result of this isolation of resource management from the wider political relations through which it had been organized and not, as is widely believed, because of an 'erosion of the autonomous functioning of village management systems' (Vani 1992:9). No longer, sustained by the wider political system which made them operable, tank systems did indeed fragment into the autonomous village systems which, by the end of the 19th century, they were widely percieved traditionally to have been. On the one hand village-based tank institutions were created as part of a 'social system decapitated by colonial rule' (Dirks 1987:8); while on the other these local traditionswhich the government later recorded and reifed as kudimaramat 
custom-were manifestly failing to invest in and maintain many tank systems. The 'creation' of traditional village institutions of tank maintenance on which the government's own public works machinery had come to depend, and their apparently widespread dissolution were both products of the same political changes effected by colonial rule. ${ }^{17}$ Moreover, the very Western engineering science which invested and defined kudimaramat custom also disregarded, limited or constantly interfered with local farmer-managed irrigation systems (IIMI/IMA 1995:5).

This is not to say that tank systems universally collapsed. The vast majority of tanks manifestly continued to function. Indeed, the ideology of decline until recently concealed from public view local water management systems, which were sustained by the demands of agriculture and underpinned by localized authority (Mosse 1997a, forthcoming-a, Sengupta 1985, 1991). However, it would be equally wrong to conclude that these local systems (often restricted to supply channel maintenance and water distribution) represent enduring autonomous village traditions persisting unchanged by wider political and economic transformations. Indeed this separation of irrigation systems (water rights, maintenance obligations) from political authority was precisely the achievement-ideological, legal (through property law) and empirical — of colonial government. In substituting village custom (backed by law) for segmentary political authority, the ideology of kudimaramat both rejected and concealed the role and obligation of political authority, including that of the colonial government, in tank management, investment and repair. As a product of 'orientalist empiricism' (Ludden 1993) kudimaramat was 'a set of "factualised" statements [about village irrigation] detached epistemologically from colonial politics' (Breckenridge and van de Veer 1993:8). In the next section I suggest that such 'orientalist' constructions of community irrigation management continue to shape development policy ideas today.

In sum then, after 1850 , a newly centralized colonial system not only required an institutionalized conception of local practice, but also required that it had the legitimacy of 'custom'. Moreover, legislation on community participation in irrigation was premised on the experience of its absence. At any rate, subsequent government intervention-including a series of irrigation bills from 1906 to $1934-3^{6}$ attempting to codify further community contributions under an

${ }^{17}$ For a similar argument applied to the jajmani system as a 'traditional' villagebased system of exchange of goods and services, see Fuller 1989a, Fuller 1989b and Mayer 1993 . 
increasingly centralized irrigation administration (Mukundan 1988:1 $5^{-18) — o n l y ~ s e r v e d ~ t o ~ a c c e l e r a t e ~ o r ~ c o n f i r m ~ i t s ~ d e m i s e . ~ A ~ c e s s ~}$ ( tax) on irrigated land to cover tank maintenance gradually replaced the idea of enforcing labour and when (in the 1930s) this was incorporated into land taxes, the government's ability to legitimize claims on villager labour, resources and management through 'custom' was finally undermined. While attempts to promote community involvement through the enforcement of custom by direct acts of law were abandoned in the 2oth century, the same function was given to village panchayats widely constituted by the 1920 . By then the powerful notion of traditional village self-government and its decline was well established as a justification for state intervention in community organizations. ${ }^{18}$ Panchayat law began to order certain regulatory activities related to tank irrigation, such as water distribution, which were hardly touched in kudimaramat Acts (Vani 1992). Like kudimaramat law, panchayats were burdened with carrying government's principles of resource management-that is the extension of community obligations but the retention of state rights. Indeed, the bureaucratization of rural institutions and the development contradiction of state directed community self-help, continued to bedevil the major postIndependence initiatives of Community Development and Panchayat Raj (see Jain 1985). Meanwhile, kudimaramat now officially understood more narrowly as farmer contributions to government-initiated works, was defined in various government orders in terms of a proportional sharing of maintenance costs between government and farmers (e.g., 4o:6o in 1963, 4:3 in 1974). At the same time, the Panchayat Unions (local government) which became responsible for all smaller tanks irrigating less than one hundred acres undertook kudimaramat work themselves and attempted to recover the cost of this 'customary' villager work from farmers (IIMI/IIMA 1995:10).

\section{Water Users' Associations (WUAs): From Tradition to Collective Action ${ }^{19}$}

As suggested at the outset of this paper, irrigation policy today is once again focusing on village management systems for tank opera-

\footnotetext{
18 e.g., The Report of the Local Self Government Committee in Madras (1882) (India Office Library).

${ }^{19}$ I am especially grateful for the contributions of Richard Palmer-Jones, Geof Wood, Peter Mollinga and David Ludden at the Madras conference on the Political Economy of Water in South Asia, which have significantly influenced the re-drafting of this section of the paper.
} 
tion, maintenance and repair. During the 1980 s and 9os, for example, major investments in Tamil Nadu tanks have been made under an EEC-funded programme of tank development. Originally conceived as a Public Works Department engineering venture to repair tank bunds, sluices and line field channels, ${ }^{20}$ this programme currently gives emphasis to the establishment of farmers' or water users' associations (WUAs) (IMTI 1993b). Following models developed in the Philippines, this aspect of the programme has been piloted in a small number of tanks by the Centre for Water Resources (CWR) of Anna University (Madras) with support for the Ford Foundation. This experiment is part of a national (and international) move towards 'participatory irrigation management' (PIM) or 'irrigation management transfer (IMT). There is no single PIM or IMT model within India and different states are presently evolving their own approaches (Brewer \& Raju 1995). This is a complex and rapidly changing subject well beyond the scope and purpose of the present discussion which is limited to identifying some continuities between contemporary participatory irrigation policy and its validating social theories, on the one hand, and the colonial discourse of kudimaramat, on the other. However, before examining these continuities it must first be recognized that today's community management strategy (implemented through collaborative arrangements involving NGOs and government) differs in significant ways from earlier policies on kudimaramat and panchayats.

Firstly, there is some recognition (although less than desired) that it is the legal enforcement of farmers' rights over tank resources, rather than their obligations that will encourage failing local initiative. Clear rights and legal authority to manage local resources are increasingly the accepted correlates of successful community irrigation management. In the NGO-led experimental project in Tamil Nadu, new WUAs take contracts directly from the PWD and retain profits which would otherwise go to private contractors. They organize construction work themselves and (in principle) maintain the improved irrigation system with resources generated through new community rights over tank resources such as trees, fish, silt and the income these generate (CWR 1990: 125-32, 1991).

Secondly, it is now reckoned that specialized village institutions (WUAs) will only be capable of managing and maintaining tanks if

20 The focus on command area development and distribution (i.e., field channel lining) was new and followed on from work on canal systems in the 1970s (Vaidyanathan 1992:14). 
they are initially supported with external resources. As a study of one informal tank institution showed, 'although ayacut (irrigated land) associations might appear to cost the government a minimal amount, they involve considerable cost to the cultivators' (Meinzen-Dick 1984). In consequence, WUAs receive focused assistance in the form of funds, technical support and training, as well as (in the GWR pilot project) the deployment of specialized field-based teams to 'motivate' and organize individuals into the new collectivities. In canal irrigation, government policy for the turnover of operation and maintenance to users throughout the state has recently (1994) taken shape under the World Bank assisted Water Resources Consolidation Project in the form of a three-tier structure of farmers' organizations with WUAs managing irrigation at the lower levels and represented at higher levels (IIMA/IIMA 1995). ${ }^{21}$ What is ultimately proposed is a state-wide 'irrigation extension' bureaucracy to support these farmers' organizations (IMTI 1993b:18-9).

Thirdly, a new principle, namely equity, is introduced (at least in the experimental tanks, but in principle more widely): WUAs are expected to manage tank resources and distribute the benefits proportionately to all 'stake holders'-large and small farmers, tenants, landless labourers and members of different castes.

While the experimental strategies for tank (and canal) irrigation transfer in Tamil Nadu display profound change in concepts of community management, and are also subject to recent influences from discourse of community development, participation and empowerment (as well as new forms of democratic accountability), the underlying problems that tank systems present to a centralized irrigation administration, the bureaucratic rationale for promoting village level institutional solutions and the conception of village society which underlie these solutions, all share much with colonial times.

For one thing, handing tank management over (or back?) to farmers' institutions is still primarily and officially viewed as a means to ease the financial burden of government in managing widely scattered and small-scale systems, by ensuring better (and local) system maintenance. If 'customary' kudimaramat institutions played an important part in the extension of a state irrigation bureaucracy in

${ }^{21}$ A Public Works Department Govt. Order (Ms. No. 1184 , dated 23.1 1.94) directs the turnover of distributary level operations and maintenance on canal systems from the Public Works Department to Farmer Councils. Such an order for tank systems is awaited. 
the late nineteenth century (effectively indicating the limits of government resources and state control), then farmers' organizations have a parallel significance (worldwide) in the reverse 'rolling back' of state bureaucracy that is occurring in the late twentieth century in response to performance deficiencies of state-managed systems, fiscal crises and donor pressure. This is manifest in policy reforms directed at the removal of state subsidies for irrigation, at promoting financial autonomy (of irrigation agencies), at cost recovery, the enhancement of farmer involvement in operations and maintenance and, through WUAs, incorporating farmers into the management of, and financial liability for, local irrigation systems. (Meinzen-Dick $e t$ al. 1994, Maloney and Raju 1994, Svendsen and Gulati 1994). It is difficult to escape the conclusion that contemporary state planning for minor irrigation management requires village level institutional solutions which are socially and financially self-supporting in the same way that the colonial Madras government needed autonomous village tradition for tank maintenance and repair. ${ }^{22}$

The leigitimizing idiom of village tradition is also often retained in recent tank development programmes. Indeed, the contemporary climate of reform has given new license to the expression of enduring ideals about the traditional village community and its irrigation institutions among policy makers. Thus, officially promoted village WUAs in Tamil Nadu are seen explicitly as the means for the revival of kudimaramat as a solution to the problem of irrigation maintenance (e.g. IMTI 1993b). Their promotion is, at one level, understood as a process of recovery and the discourse of tank development is pervaded by the idea of lost tradition and therefore with the language of 're-habitation', 'restoration', 'revival of tradition', 'regeneration of farmer management' (etc.). Further, the language of local institutional development uses notions like animation, motivation, or catalysts which convey the idea of retrieval of latent community capacities.

In non-governmental and environmentalist circles the ideal sustainable relationship between communities and their environment in the past is more explicitly a goal or model for present development (Agarwal and Narain 1989), and tank systems provide an exemplary

${ }^{22}$ Programmes for major canal irrigation development also require village-level solutions in the form of 'farmer organisations', through which cost recovery can be effected and enhanced water rates charged (i.e., water can be sold to farmer organisations who recover costs from individual members) (Svendsen \& Gulati 1994). 
model for this (e.g., Shankari and Shah 1993). Traditional systems, here, also provide a critique of the 'modernising' development strategies of the centralized state, and of the dominance of technical over social perspectives. ${ }^{23}$ The idea of 'traditional' irrigation management today, then, on the one hand supports the state's own (new) administrative regime for decentralized resource systems, but on the other, legitimizes moves to reduce state control in favour of community resource rights and control. In any event, the point of reference is often the same, specifically, pre-colonial village tradition-those institutions of the local community which maintained tanks until they were weakened by British rule. ${ }^{24}$ The ideological notions of village autonomy implied in the establishment of farmers' associationsi.e., 'farmer control', 'self-management' or the elimination of middlemen and contractors-are as much nationalist as colonial, helping constitute "the well disciplined lifestyle at village level to mould and shape "Rama Rajyam" at village level as dreamt by the leaders of India such as Mahatma Gandhi and Pandit Jawaharlal Nehru' (IMTI 1993b:11).

Indicating the ideological nature of 'traditional' resource management systems does not, I should re-emphasize, mean that villagebased systems do not exist. Even though a recent review of common property resource use in Tamil Nadu found much evidence for 'a powerful ideology of the existence of popular institutions of selfgovernment which persists even in the absence of such institutions' (Blaikie et al:: 1985:65), other studies, including my own, demonstrate the continuing operation of village-level systems of tank management today (e.g., Meinzen-Dick 1984; Janakarajan 1989; 1991; Rajagopalan n.d., Mosse 1997a, 1997c) although their failure of conform to official expectations, about the 'village republic' and its corporate institutions often makes them invisible (ibid.; Sengupta $\left.19^{8} 5: 1931\right)$. Indeed, the generalized notion of the decline of rural institutions continues to contribute to an under-recognition of village systems of resource use, as it had done also in colonial times. In fact, as in colonial times, remarkably little attention has been given to the actual organization of indigenous tank management.

As a result, 'traditionalised' village tank systems are still misconceived in the image of desirable development outcomes-for

\footnotetext{
${ }^{23}$ Perhaps it is significant that while the engineering-led PWD project is entitled, 'tank modernisation', NGO programmes use phrases such as 'tank rehabilitation' or 'the regeneration of farmer management' in their titles.

${ }^{24}$ See, IMTI 1993a (passim); IMTI 1993b; DRDA \& Pradan 1994.
} 
example, as equitable and efficient, as involving corporate organizations, as independent from external power and resources, or as isolated from the wider impacts of change in caste and political relations. A corrective and, in my experience, more common picture is provided, for example, by the process documentation reports of the Anna University tank project, from which it is clear that pre-existing shares (pangu or karai) systems of water distribution (on which new WUAs have loosely been based) are often technically inefficient, ensure unequal access to water at times of shortage and for this reason are often the focus of local dispute (see Mosse 1995a, 1997b, for an analytical account drawing on these sources). Indeed, such 'traditional' systems often function as institutions of upper caste dominance, and are, in fact, vestiges of a much wider set of castebased privileges and rights over village resources. They are often surprisingly bad at managing common resources and a dubious model for contemporary water users' associations (see Mosse 1997a, forthcoming-a). But the point is not simply that notions of irrigation tradition continue to misconceive local tank systems, but that they do so in socially significant ways; that is, in ways which meet persisting (and new) administrative needs for autonomous, selfmanaged and functionally-focused systems.

A third continuity with colonial notions of community management in south India is the conjunction of the belief in the 'decay of village corporate life' with ideas about the superiority of 'modern' organizational forms-the desire to formalize, codify and generalize local practice. This has long provided a rationale for 'organizing farmers' into pre-defined forms of institution, recognizable as such by officials, i.e., formal irrigation cooperatives, farmers' societies, water users' associations, which, like kudimaramat in its time, meet a variety of official expectations about the way people ought to organize themselves. The transfer of new 'social technologies'-including criteria for group membership, roles and offices, conduct of meetings, record and account keeping (etc.)-determine new types of social boundary and new forms of procedural efficiency. They serve to meet the administrative needs of irrigation development agencies (official or voluntary) by providing a means to consult with people, to harness local leadership, mechanism to channel development inputs, and meet (public and private sector) bureaucratic requirements of orderliness, uniformity, quantifyability and control.

Without denying the advantages, and necessity, of legally constituted formal irrigation organizations (e.g. their capacity to empower 
farmers in their dealings with external authority) such institutions are often conceived in ways which provide a simplification of both the social organization of local irrigation systems and the politics of institutional change (ibid.). But, as with kudimaramat custom, this simplification, uniformity and standardization are essential to a recasting of the social organization of tank irrigation in bureaucratic terms. The unit of administration becomes the homogenized villagelevel farmers' association reproduced, potentially, in thousands of villagers. Here, as with the emerging colonial state of the 1860 s and 70 , a centralized bureaucracy constructs and employs its own image of tank maintenance traditions, and its own concepts of institutional efficiency. In particular, government administration of farmers' organizations for tank management in south India continues to emphasize government's concern with maintenance and falls short of the more radical new policy on the transfer of rights in resources (e.g. rights to collect water charges or ownership rights) or public contracting to farmers. The state has lost little control over irrigation resources. Indeed arguably, state promoted and legally constituted water management institutions will not only relieve government of maintenance functions, but will also provide new mechanisms to regulate rural society and extend the state's administrative capacities.

However, as has recently been pointed out, overriding orientation to the bureaucratic needs of officials rather than farmers has often rendered farmers' irrigation organizations managerially dependent and ineffective (cf. Ostrom 1992:11) or has, at worst, eroded rather than strengthened local collective action (e.g. Pandian 1990). Such problems, compounded by the state retention of rights to tank resources, are addressed in the latest trends in theorizing irrigation institution development and by NGO initiatives in the state. In as much as they are part of a world-wide interest in 'turnover', such initiatives are informed by new theories of local irrigation institutions which focus not on uniform organizational form and boundaries (uniform rules, membership, procedures etc.) but on the contextspecific structure of incentives which determine the collective provision of rules for common resource use and which motivate strategizing individuals to commit themselves to follow them (Ostrom 1990, 1992, Tang 1992).

The analysis of institutions in terms of individual costs/benefits of rule following (and the monitoring of co-users of a resource) rather than timeless village tradition or model committees, is emerging at 
a time when strongly centralized state administration in many countries is under pressure from new ideologies of privatization and free market. If, as I have argued, sociologies of village irrigation tradition are, in a sense, shaped by particular forms of government, it may not be surprising to see, under the global (and especially from 1991, Indian) re-emphasis on the free market and private management, a reformulation of old communal ideas within the irrigation policy community. In this externally driven ideological reorientation, farmers (or ryots-colonial tenants/subjects) become 'users' or 'appropriators', their customs and traditions become 'social or institutional capital', and village organizations become 'water management associations' (Maloney \& Raju 1994, ${ }^{25}$ Ostrom 1990). Irrigation systems in India are themselves conceived less as part of a 'nexus of community and land which [link] local society to the [colonial] state' (Gilmartin 1994:1133), and more as businesses in which commercial arrangements link clients and supply agencies.

I have no intention of critically reviewing the important contribution of the interrelated fields of public choice theory, transaction cost economics or game theory, which are involved here, and which might loosely be labelled institutional-economic models of 'collective action'. Considering, however, the commanding position in policy discourse which their constructions of community irrigation management are acquiring it may be useful (a) to consider what selective emphasis this analysis brings to bear on rural society, and, related to this, (b) to try to account for its emerging dominance within agency discourse on resource management, in the same sociological terms which were used in relation to colonial notions of custom and tradition.

On the first point, there is a concern that much of this policyoriented analysis carries implicit assumptions about the sufficiency of an 'economic' modelling of resource use, to the exclusion of political and cultural perspectives which may be of considerable local and practical importance. It is true that recent work is more cautious about the economic modelling of human behaviour. Ostrom, for example, suggests that earlier theories of collective action built in too many assumptions to be useful to policy (1990:191). Employing a more open-ended set of 'situational variables', she proposes a 'framework for analysing institutional choice' rather than a particular

\footnotetext{
25 'Reporting on the National Workshop on Farmers' Management in Indian Irrigation Systems', Hyderabad February 1992.
} 
(restrictive) model (ibid.:214). This qualifies but does not, however, question the basic idea, employed in popular development discourses, that the economics of resource use (individual costs/benefits) provides an independent principle of social organization; independent, that is, of historically determined and culturally specific notions of 'resources', rights, obligations (etc.) which tie resource management to wider social and political forms. As one detailed study of a village tank system in Tamil Nadu, carried out in the institutional analysis tradition, concluded

local water management activities are unlikely to be embedded in the institutions of village, caste or religion' rather efficient maintenance, allocation, and conflict management requires special purpose organisations of ayacut [irrigated land] cultivators specifically for irrigation management, with benefits from better water supply as the motive for organising (Meinzen-Dick 1984:46). ${ }^{26}$

What is at issue here is the imposition of a narrow definition of economic interest, utility and value, to the exclusion of the wider range of symbolic resources and political interests involved in the management of tanks as common or 'public' village resources (see Mosse $1997 \mathrm{c}$, for a discussion of these symbolic interests). The operational success of irrigation organizations becomes narrowly determined by factors such as the nature of the resource (its boundedess, seasonality, visibility, etc.), the tasks to be performed (water acquisition and allocation, system maintenance, conflict management etc.) and the distribution of benefits within the group (see also, Wade 1987, Bagadion \& Korten 1991, Uphoff 1986, Gurtis 1991). These are, of course, the prime development concerns; and the description is, after all, intended to meet criteria of policy 'usefulness' as much as those of sociological accuracy. The point is that what policy informed by contemporary collective action theory shares with colonial irrigation administration is precisely this separation of village resource management from wider political relationships and historical context. In a sense, its 'design principles' and its idioms of 'individual strategy', or 'social capital' are as static, ahistorical and apolitical as the colonial idioms of 'tradition' and custom. For example, the economistic notion of social relations as 'capital' which can be carefully tapped, invested or transferred to meet development

\footnotetext{
${ }^{26}$ The quotation is selected purely for its succinctness. Meinzen-Dick's subsequent research suggests the particularity of this rather functionalist conclusion (pers. comm.).
} 
ends (or wasted) (e.g., Ostrom, Schroeder and Wynne 1993), implies a static store of consensual cultural practices which comes close to colonial ideas of 'tradition'. Both colonial and contemporary irrigation social theory divert interest of planners away from social actors and their wider networks, take little cognisance of the fact that social action in the context of common or public resources is markedly political, that relations of power underlie rule conformity, or that individual strategies are themselves mediated by social institutions whose elements (concepts, values and meanings) are constituted in culturally and historically specific ways (Douglas 1986). But (and this is the next point), it is precisely by this denial of power and history, that models of custom or collective action are able to provide the generalizing and predictive models required as a basis for rural administration or programme planning.

In contrast to dominant models, current lines of enquiry suggest that the management of tank resources has rarely provided an independent organizing force in rural Tamil Nadu, in the sense that farmers' relationships to irrigation water resources are not at all isolable from their relationships with each other, mediated by institutions and idioms of caste, kinship, political office or temple honour. Indeed, as Leach's (1961) now classic study of tank irrigation in Pul Eliya (Sri Lanka) showed, it is often impossible to separate out the 'facts of property' - land and water-from political or kinship structures through which they are represented and 'talked about'. Not only has resource control, historically, been represented in the idioms of caste status, political authority or temple honours (cf. Ludden 1985, Dirks 1987) and not only do these encode dominant interests, but also, rights in resources-in this case public water resources-are themselves often an idiom of political relations or social standing (Spencer 1990:100-1). In other words, land and water in south India are not only exploitable resources but also media through which a variety of social relations have been structured (Granda 1984:3). This is particularly evident in the case of the public or common resources of tank irrigation. Above all, irrigation tanks are social systems in which water management involves institutions ('indigenous' or established by projects) defined by cultural conceptions of authority, property, rights, entitlements and obligations, and which express and are reproduced by changing social and political relations.

In the detail of individual cases this is self-evident. Drawing on the micro-level detailed 'process documentation' of the Centre for 
Water Resources researchers, I have examined the nature of one particular village tank association as a political institution. ${ }^{27}$ It is clear that the local tank and its supporting water users' association (WUA) provided resources which were not just economic, but also political and symbolic. Not only was the water users' association shaped by villagers' political strategies, but also the development programme through which it was promoted underlined and amplified this political significance. New resources, additional sources of patronage, and a wider 'public' brought by the project meant that the WUA was, in fact, uniquely placed to articulate caste and factional conflicts. But further, if through development interventions natural resources also became political resources, they did so in culturally and historically specific ways. In the village case, the political and symbolic significance of the tank as a common property resource rested on a particular Tamil (or south Indian) conception of the 'public domain' of which it was a part. The 'public', in this case, is the domain of authority, of rank and caste status (cf. Price 1991). It is the field for political strategizing. Public affairs concerning village resources (material or symbolic; tank or temple) articulate positions of power, social standing and caste status; and conversely provide opportunities to challenge authority, canvass political support, to articulate factional affiliation, or organize caste protest (see Mosse 1997a, 1997c).

From this perspective, tank institutions, their continuity and their leadership cannot be conceptualized (as in collective action models) primarily in terms of the benefits of reduced transaction costs of irrigators without recourse to a very limited concept of human agency (Mollinga 1995). As the caste conflict, factional disputes and litigation which characterized the operation of the new WUA in the village case cited suggest, institutional 'crafting' (Ostrom 1992) may not be able to counter 'perverse incentives' in predictable ways (Tang 1992: 126). Where they encourage the rendering of local historical and social factors as, at best, of secondary importance and, at worst, as unanalysable random occurrences of marginal relevance to planning predictable outcomes, institutional analyses and their 'design principles' contribute tools for planning which prove only partially useful in practical tank development work.

\footnotetext{
27 A summary of the formation and functioning of the water users' association of Nallaneri village is given in Mosse 1997b. This is based on process documentation records kept by field staff of the Centre for Water Resources from September 1988 to October 1994, and brief field visits during 1994.
} 
Collective action models not only tend to encourage overly functionalist interpretations of institutions, but also to endorse the construction of WUAs as autonomous, self-managed, and spontaneous institutions (influenced by external factors, to be sure) but basically internally sustained by a structure of incentives in relation to resources use. These models define 'community management' in terms of local equilibrium of steady state systems which are compatible with the (global) discourse (policy and programme practice) oriented towards finding community solutions to the perceived problems of state and market-based water control and management. In fact, these notions of 'community management' are often rooted in and validated by internationally funded irrigation development programmes in which programme experience, policy and theory become mutually validating (Palmer-Jones 1995). As Palmer-Jones (1995) points out, programme 'success' becomes defined in terms of the presence of associations, or membership, or rule conformity; that is in terms of the prescriptions of the model itself. Descriptive accounts of community irrigation management identify characteristics of success, which are then interpreted as generalized conditions for, or determinants of, collective action (e.g. Tang 1992).

As a self-validating set of ideas, the policy and theory of WUAs has little to say about situations where such institutions do not exist, are discontinuous or how they perform by criteria of success other than its own (e.g., productivity, ecological sustainability) (ibid.). Another problem is that the supporting empirical material is often derived from case studies and project-defined success stories. Some recent commentary suggests that the still rather limited experience with self-managed community irrigation may not be as successful (even in its own terms) as the first enthusiastic reports suggested. As Palmer-Jones notes, the exceptional allocations of human and financial resources put into well publicised innovative pilot projects, together with agency needs for good news stories, can conspire to give a misleading picture of the performance of WUAs in the long term, on a larger scale, or on closer examination.

In particular, community management discourse serves to mask the considerable role of external resources and actors-community workers, project staff, agency representatives, government officialsin institution formation, rule consensus, enforcement, power brokering, conflict mediation, arbitration, resource acquisition and so forth (see Mosse 1997b). How often are the 'incentives' of contractors, PWD officials, political leaders, NGO workers, donor repres- 
entatives, or researchers, taken into account in the crafting of institutions? And yet external power, resources and values directly and indirectly determine the form of, and support the functioning of WUAs (ibid.). Questions here concerning the sustainability of externally promoted 'community management', whether under NGO or government programmes, remain largely unanswered.

But further, for farmers themselves, the very meaning and purpose of new WUAs has to do with linkage to external authority. WUAs operate as mediating institutions for access to external power and resources (and it is by virtue of this function also that they articulate local political conflict). Indeed, village tank management 'institutions' in pre-colonial times - which involved land grants, titles and rights granted by the overlord (warrior/king)—equally found their political meaning in the articulation of links between the local village and wider political authority (Mosse, n.d.). In common with colonial notions of kudimaramat tradition, then, collective action theory constructs as 'spontaneous' and self-sustaining, institutional solutions which are, in reality, conceived, imposed, and in most cases, sustained by substantial external authority and resources.

The issue here is not only selectivity in description or reporting, but also in the application of theory. What elevates the emphasis on community management from the limited realm of organizational policy to that of universally valid social theory is its expression in terms of rational choice models and game theory. But, as PalmerJones again points out, game theory shows that cooperation is possible, not that any particular cooperative outcome is necessary (ibid.). I do not wish to suggest that incentive structures are not important or that problems such as the 'free rider' are not real dilemmas in local tank management. These are practically useful theoretical acquisitions. Rather, the points that I am making are, firstly, that rational choice modelling leaves much out, and secondly, that notions of self-government are strongly ideological. Ideas of autonomous selfgoverning community irrigation management within irrigation bureaucracies today, whether founded on notions of tradition or collective action, are no less ideological than kudimaramat, and in this sense can misrepresent as well as guide local institutional development. Equally, (and to reiterate), my argument here does not imply criticism of the policy goal of participatory irrigation management (any more than the kudimaramat discussion questioned the importance of understanding and interacting with farmer-managed tank systems). Rather, it focuses on the selectivity and limitation of the 
models of community and collective action in terms of which, policy is conceived and, practice interpreted. ${ }^{28}$

The next question to ask is, how do these particular ideas or models (i.e., of self-governing institutions) come to have dominance within policy making communities? The answer is, perhaps selfevidently, that given social theories are sustained by their particular correspondence with the concerns of given administrative or development regimes; they acquire their validity and power from their uses within development institutions. As Mary Douglas, drawing firmly on the sociological tradition of Durkheim, insists, institutions classify and make choices. Our policy problems are posed and solutions found within institutions which:

systematically ... channel our perceptions into forms compatible with the relations they authorise. They fix processes that are essentially dynamic, they hide their influence ... they endow themselves with rightness and send their mutual corroboration cascading through all levels of our information system ... problems are automatically transformed into their own organisational problems. The solutions they proffer only come from the limited range of their experience. If the institution is one that depends upon participation, it will reply to our frantic question: 'More participation!' If it is one that depends upon authority, it will only reply: 'More authority!' (1987:92)

The same, of course, goes for irrigation bureaucracies which have for long depended upon local self-management or collective action in dealing with tank irrigation. Irrigation policy ideas such as kudimaramat tradition and self-governing local institutions are socially constructed, they are social facts, part of policy-making as a collective enterprise advancing institutional interests. But these ideas rapidly cease to be mere statements of operational strategy and become linked to theorized bodies of knowledge about rural society and the way it works, 'substantiated according to the scientific standards of the day'-whether these be commissions of enquiry on kudimaramat presenting the observations of authorized European officers in the Enlightenment rubric of objective science (Ludden 1993:252); or

\footnotetext{
${ }^{28}$ Also, my argument is not intended as a contribution to a disciplinary boundary dispute between anthropologists and economists. Firstly, many economists and the theoretical models they employ dispense with unrealistic assumptions about people as self-interested economic maximizers and focus on relationships between actors, on norms, expectations and other forms of assurance, trust or habit which influence cooperative outcomes (cf. Seabright 1993, Runge 1986). Secondly, many economists admit the importance of complementary explanations dealing with social phenomena falling outside the standard domain of economic enquiry (Vanberg 1994:6-7; Ruttan 1986, cited in J. Kynch pers. com.).
} 
observations on collective action 'solutions' authorized by economic models of rational choice behaviour which command the position of dominance in contemporary development discourse. I am not suggesting that development institutions (irrigation bureaucracies and donor agencies) are the creators of social theory, merely that they constrain and select theory, nudge the thinking of their members in particular directions, and impose particular interpretations (ascribe motivations etc.) on observed behaviours.

The colonization of minds by institutions is an element in the multiple relationship between power and knowledge shown by Foucault's work, and Foucault's work provides a point of departure for Edward Said's exploration of the rootedness in imperial power of one hegemonic form of knowing 'the other'—orientalism. Recent Indian historical scholarship has been influenced by, but not limited to, Said's (1978) notion of 'orientalism'. In particular, recent work shows that 'Orientalism . . . is not just a way of thinking ... [but] a way of conceptualizing the landscape of the colonial world that makes it susceptible to certain kinds of management' (Breckenridge \& van de Veer 1993:6). I have tried, in this essay, to demonstrate the pertinence of this to the tank irrigation 'landscape' in south India. The discourse of kudimaramat and village tradition provides an illustration of the way in which, as Ludden puts it 'colonial governance constructed [a] concordance between empirical evidence and social theory by weaving orientalism as a body of knowledge into the fabric of administration and law' (1993:266). Secondly, I have suggested that the 'colonial project to organise and rule Indian society' (ibid::4), perhaps, has its contemporary (international) development equivalent which employs a type of knowledge (rooted in programmes) which is, in its own way, also 'orientalist'. ${ }^{29}$ (Meanwhile, the notion of the traditional village community and its irrigation institutions, freed from its instrumental function under colonial government, has now been able to acquire new political meanings within nationalist, and more recently, environmentalist discourses).

This discussion of policy concepts and social theories finds a parallel in literature on 'labelling' in development (Wood $19^{8} 5 \mathrm{a}, 19^{8} 5 \mathrm{~b}$ ). ${ }^{30}$ Kudimaramat or 'user group', are labels in the same way as 'beneficiary' or 'participant' are. Labels serve to 'stabilize the flux of life'; but

\footnotetext{
${ }^{29}$ I am grateful to Richard Palmer-Jones for his conference paper (1995) which also identifies 'orientalist' elements in contemporary irrigation development policy.

${ }^{30}$ I am grateful to Geof Wood for drawing my attention to this parallel.
} 
not only this, they also change behaviour and create (or eliminate) the realities they identify (Douglas 1987:100). The bureaucracy or development agency has a capacity to impose the label and effect the change. But to emphasize this power is to understate the agency of the labelled themselves. In development contexts (and tank irrigation is no exception) labelling directs the flow of external resources and inputs. Given the material and political benefits (funds, political support) to be gained through doing so, rural society often transforms itself towards the label (ibid.). In response to the institutional development policy aims of government and non-government organizations, cooperative groupings of a huge variety of kinds now characterize rural Tamil Nadu. Indeed, 'committees', 'groups', 'societies', 'associations' and 'councils' are increasingly seen by village actors as the legitimate means to petition for and acquire development resources, and such 'groups' now appear in the absence of external interventions. As farmers' associations become a more central part of minor irrigation policy in the state, the advantages and incentives of forming associations will also increase, although these will always be balanced by the disincentive of increased external bureaucratic interference (e.g., the unwanted auditing attention of the cooperative sub-registrar, or the politicians' demand for donations from the Society fund). Interestingly, the effect of the kudimaramat label was exactly the reverse. Because the label implied community obligation backed by penal sanction, it was a category of collective action which rapidly became empty; a label from which people fled.

In Tamil village society all are not equally placed to articulate their interests through the new institutional forms, (or to avoid coercion under older colonial ones). There are important relations of power (e.g., of gender and caste) at work in the 'community construction of community', and an often concealed politics of 'consensus' rulemaking. The ability to shape rules and control new institutions, and the ability to use these to 'officialize' private or group needs or social ambitions as the village public good is itself an expression of dominance (Bourdieu 1977). As already emphasized, tank institutions are constituted by and express relations of power and authority, and these social meanings do not disappear, may in fact be amplified, with the establishment of new special purpose organisations, such as 'water users' associations' under the EEC tank programme (Mosse 1997b). But equally, social dominance does not remain unchallenged by new institutions which also provide the means to advance externally defined development objectives such as equity, democracy and social justice. Formal resource management institutions usually introduce 
new systems of representation, accountability and public decision making, which involve new caste or gender roles, defined by project equity objectives. The point is that these social changes intersect with local caste conflicts or factional affiliation, and with strategies to challenge as well as retain caste power. In the village case referred to earlier, the political nature of the formal WUA was unmistakable when it became the focus of litigation which halted EEG tank development works for nearly two years (Mosse 1997b). So, institutions of water management are continually renegotiated in ways which bring into play public honour, caste status and political ambition, as well as the need for a secure water supply. They are part of the success and failure of the reproduction of local social dominance. The policy constructions of community institutions discussed in this paper, however, tend to obscure these development dynamics, unless they erupt into sight through conflict (and for this reason the analysis of conflict is especially important). But perhaps even more importantly, today's policy constructions of community management conceal the political agency of development institutions themselves, just as notions such as kudimaramat concealed colonial politics. The construction of 'apolitical' models of rural society is itself highly political.

In focusing on the nature of knowing society in the context of rural development policy, this paper has attempted to show that underlying 'social theories' of community management are institutional constraints to the recognition of those least manageable aspects of rural society, the political and cultural. And yet, the incorporation of analysis of power, meaning and social complexity is especially crucial to implementing policy, and specifically to evolving effective local strategies for institution development. The methodological challenge which the need for such decentralized and reflexive social analysis presents to development planning has barely been addressed (see Mosse 1998, Mosse 1995b). For one thing, participatory research methods (e.g., Participatory Rural Appraisal-PRA), which have gained wide currency recently are weakest when it comes to the analysis of social relationships, those relations which set the social conditions for participation itself (ibid.). But, finally, it may be helpful to be reminded that there are other, different, traditions of 'collective action'-collective action as struggle and protest-in which people's organisation is firmly built on the critical analysis of local structures of power and oppression. ${ }^{31}$

\footnotetext{
${ }^{31}$ I am grateful to Geof Wood for pointing out the polarity between rational choice models of collective action, and collective action as (political) struggle.
} 


\section{References}

Abeyratne, S. 1990. Rehabilitation of small-scale irrigation systems in Sri Lanka: state policy and practice in two systems. IIMI Country Paper-Sri Lanka-No. 6. International Irrigation Management Institute: Colombo.

Agarwal, A. and Narain, S. 1989. Towards green villages: a strategy for environmentally-sound and participatory rural development. Delhi: Centre for Science \& Environment.

Ambler, J. 1992. Basic elements of an innovative tank rehabilitation programme for sustained productivity, unpublished paper, Ford Foundation, New Delhi.

Ambler, J. 1993. Financial and institutional challenges for tank sustainability: some historical lessons. Keynote address, 'Think Tank Seminar' Madras, July 1993.

Appadurai, A. 1981. Worship and conflict under colonial rule. Cambridge: Cambridge University Press.

Bagadion, B.U. and Korten, F.F. 1991. 'Developing irrigators' organisations: a learning process approach'. In Putting people first: sociological variables in rural development (second edition). Oxford: Oxford University Press; Washington D.G.: The World Bank.

Baker, C.J. 1984. An Indian rural economy 1880-1955: the Tamilnad countryside. Oxford: Clarendon Press.

Blaikie, P.M., J.C. Harriss and A.N. Pain. 1985. Public policy and the utilisation of common property resources in Tamil Nadu, India. Overseas Development Group and School of Development Studies, University of East Anglia. Report presented to the Overseas Development Administration.

Bourdieu, P. 1977. Outline of a theory of practice (Trans. R. Nice). Cambridge: Cambridge University Press.

Bromley, Daniel W. and Michael M. Cernea. 1989. The Management of common property natural resources: some conceptual and operational fallacies. World Bank Discussion Papers, No. 57. Washington D.C.: The World Bank.

Breckenridge, C. and P. van de Veer (eds). 1993. Orientalism and the post colonial predicament: perspectives on South Asia. Philadelphia: University of Pennsylvania Press.

Brewer, J.D. and K.V. Raju. 1995. Irrigation Management Transfer policies and law. International Irrigation Management Institute. Paper for workshop on Irrigation Management Transfer in India. Ahmedabad, 11-13 December, 1995.

Coward, E. Walter Jr. 1991. Planning technical and social change in irrigated areas. In M.M. Cernea (ed.) Putting people first: sociological variables in rural development (2nd edition) Oxford: Oxford University Press, and Washington D.C.: The World Bank.

Curtis, D. 1991. Beyond government: organisations for common benefit. London and Basingstoke: Macmillan.

CWR. 1990. Alternative approaches to tank rehabilitation and management-a proposed experiment: annual report 1988-89. Centre for the Water Resources, Anna University, Madras.

CWR. 1991. Alternative approaches to tank rehabilitation and management-a proposed experiment: annual report 1989-9o. Centre for Water Resources, Anna University, Madras.

Dirks, N. 1987. The hollow crown: ethnohistory of a south Indian little kingdom. Cambridge: Cambridge University Press.

Djurfeldt, G. and S. Lindberg. 1975. Behind poverty: the social formation in a Tamil village. Scandinavian Institute of Asian Studies Monograph Series No. 22. London: Curzon Press.

Douglas, M.1986. How institutions think. London: Routledge \& Kegan Paul. 
DRDA \& PRADAN. 1994. Discussion papers: Seminar on regeneration of farmers' management of tank irrigation systems', March 1-2. District Rural Development Agency (DRDA), Madurai \& Professional Assistance for Development Action (Pradan), Madurai.

Elumalai, G. 1982. Modernisation of tank irrigation systems: farmers' views. Paper presented at the workshop of Tank Irrigation: Problems and Prospects, Centre for Water Resources, Madras.

Fuller, C. 1989a. British India or traditional India? Land, caste and power. In Hamza Alvi and J. Harriss (eds) South Asia. Sociology of Developing Societies. London: Macmillan.

- $1989 \mathrm{~b}$. Misconceiving the grain heap: a critique of the concept of the Indian Jajmani system'. In J. Parry and M. Block (eds) Money and the morality of exchange. Cambridge: Cambridge University Press.

Gadgil, Madhav and Ramachandra Guha. 1992. This fissured land: an ecological history of India. Delhi: Oxford University Press.

Gilmartin, D. 1994. Scientific empire and imperial science: colonialism and irrigation technology in the Indus basin. J. Asian Studies 53, 1127-49.

Granda, P.A. 1984. Property rights and land control in Tamil Nadu: 1350-I6oo. PhD Dissertation, University of Michigan.

Gulati, A. and S. Bhide. 1995. The 1995-96 Budget and economic reform: What do reforms have for agriculture? Economic and Political Weekly, Vol. xxx, No. 18 19: 1089-93.

Harriss, J. 1982. Capitalism and peasant farming: agrarian structure and ideology in northern Tamil Nadu. New Delhi: Oxford University Press.

IIMI \& WUHEE 1994. International conference on irrigation management transfer: Draft conference papers. Vols 1-3, 20-24 September 1994. International Irrigation Management Institute and Wuhan University of Hydraulic and Electrical Engineering, Hubei Province, P.R., China.

IIMI/IIMA. 1995. A survey of irrigation management transfer policies and activities in Tamil Nadu (Draft). International Irrigation Management Institute/Indian Institute of Management, Ahmedabad.

IMTI. 1993a. Seminar on EG assisted Tank Modernisation Project Phase II Extension: Alternative strategies and new initiatives. 6-7 December 1993 (Collected papers). Irrigation Management Training Institute, Tamil Nadu.

IMTI. 1993b. Working paper on organising farmers' associations. Water Resources Consolidation Project (World Bank). Irrigation Management Training Institute, Tamil Nadu, March 1993 .

Jain, L.C. 1985. Grass without roots: rural development under government auspices. New Delhi: Sage Publications.

Janakarajan, S. 1989. Characteristics and functioning of traditional irrigation institutions. In Management of renewable resources. Special section of Bulletin, Madras Development Seminar Series, Vol. XIX, No. 12, December.

- 1991a. The extent and impact of ground water irrigation in Tamil Nadu: some macro and micro evidences. Working Paper, No. 102. Madras Institute of Development Studies, Madras.

—. 1991b. In search of tanks: some hidden facts. Working Paper, No. 97. Madras Institute of Development Studies, Madras.

Lardinois, R. 1989. Deserted villages and depopulation in rural Tamil Nadu, c. 1780-c. 1830. In India's historical demography (ed.) T. Dyson. London: Gurzon Press.

Leach, E.R. 1961. Pul Eliya. Cambridge: Cambridge University Press.

Li, T.M. 1996. Images of Community: discourse and strategy in property relations. Development and Change 27, 501-27. 
Ludden, D. 1979. Patronage and irrigation in Tamil Nadu: a long-term view. The Economic and Social History Review, Vol. 16, No. 3.

-. 1985. Peasant history in south India. Princeton: Princeton University Press.

—. 1992. India's Development Regime. In Colonialism and culture (ed.) N.B. Dirks. Ann Arbor: University of Michigan Press.

-. 1993. Orientalist empiricism: transformations of colonial knowledge. In Orientalism and the post colonial predicament: perspectives on South Asia. (eds) C.A. Breckenridge and P. van der Veer. Philadelphia: University of Pennsylvania Press.

Maloney, C. and Raju, K.V. 1994. Managing irrigation together: Practice and policy in India. New Delhi: Sage Publications.

Matthai, J. 1915 . Village government in British India. London: T. Fisher Unwin.

Mayer, P. 1993. Inventing village tradition: the late 19th century origins of the north Indian 'jajmani system'. Modern Asian Studies 27, pp. 357-95.

Meinzen-Dick, R. 1984. Local management of tank irrigation in south India: organisation and operation. Cornell Studies in Irrigation, No. 3. New York: Cornell University.

- 1989. Water in a thirsty land: irrigation development and agrarian structure in south India. unpubl. PhD. dissertation, Cornell University.

Meinzen-Dick, R.M. Mendoza, L. Sadoulet, G. Abiad-Sheilds and A. Subramanian. 1994. Sustainable water users associations: lessons from a literature review. Paper prepared for World Bank Water Resources Seminar, 13-15 December.

MIDS. 1983. Tank irrigation in Tamil Nadu: Some Macro and Micro Perspectives. Madras Institute of Development Studies: Madras.

MIDS (Madras Institute of Development Studies). 1988. Tamilnadu Economy: Performance and Issues. Oxford \& IBH Publishing: Delhi.

Mollinga, P. 1995. Constituencies and commands: the role of politicians in water control in a south Indian large scale canal system. Paper presented at International Conference on The Political Economy of Water in South Asia, Joint Committee on South Asia Social Science Research Council American Council of Learned Societies and Madras Institute of Development Studies. 5-8 January, 1995 .

Mosse, D. 1994. Authority, gender and knowledge: theoretical reflections on the practice of Participatory Rural Appraisal Development and Change, Vol. 25, No. 3, pp. $497-5^{2} 5$.

- 1995a. Local institutions and power. The history and practice of community management in the development of tank irrigation systems in south India. In Power and participatory development: Theory and practice (eds) Wright, S. and Nelson, N. London: Intermediate Technologies.

-. (with the KRIBP Project team) 1995b. Social analysis in participatory rural development. IIED Participatory Learning and Action (PLA) Notes, No. 24, October 1995 .

- 1997a. Ecological zones and the culture of collective action: the history and social organisation of a tank irrigation system in Tamil Nadu. South Indian Studies, No. 3, pp. 1-88.

- 1997b. The idealogy and politics of community participation: tank irrigation development in colonial and contemporary Tamil Nadu. In (eds) R. Grillo and R.L. Stirrat. Discourse of development: anthropological perspectives. Berg Publishers.

- $1997 \mathrm{c}$. The symbolic making of a common property resource: history, ecology and locality in a tank-irrigated landscape in South India. Development and Change (under review).

-. 1998. Process-oriented approaches to development practice and social research: an introduction. In (eds) Mosse, D., Farrington, J. and Rew, A. Development as Process: Concepts and methods for working with complexity (Provisional title). 
-. n.d. Irrigation and statecraft in Zamindari South India. Paper for the workshop on 'The Anthropology of the Indian State'. London School of Economics, May 1998.

Mosse, D. in preparation. The history and social organisation of tank irrigation systems in Tamil Nadu (provisional title).

Mukundan, T.M. 1988. The ery systems of south India. PPST Bulletin 16, 1-33.

Nelson, N. and S. Wright. 1994. Power and participatory development: Theory and practice. London: Intermediate Technologies.

Ostrom, E. 1990. Governing the commons: the evolution of institutions for collective action. Cambridge: Cambridge University Press.

- 1992. Crafting institutions for self-governing irrigation systems. San Francisco: Institute for Contemporary Studies Press.

Ostrom, E, L. Schroeder and S. Wynne. 1993. Institutional incentives and sustainable development: infrastructure policies in perspective. Boulder and Oxford: Westview Press.

Palanisami, K. 1981. Irrigation tank rehabilitation. New Irrigation Era 19 (3), 36-7.

Palanisami, K. and W. Easter. 1983. The tanks of south India: a potential for future expansion in irrigation. University of Minnesota, Institute of Agriculture, Department of Agricultural and Applied Economics. Economic Report, ER 83-4.

Palanisami, K., R. Meinzen-Dick and M. Svendsen. 1994. Sustaining tank irrigation: conjunctive use of tank and well water in Tamil Nadu. In Svendsen and Gulati (eds) 1994.

Palmer-Jones. 1995. Water markets and water management in South Asia. Paper presented at International Conference on The Political Economy of Water in South Asia, Joint Committee on South Asia Social Science Research Council American Council of Learned Societies and Madras Institute of Development Studies. 5-8 January, 1995 .

Pandian, M.S.S. 1990. The political economy of agrarian change: Nachilnadu I880-1939. New Delhi: Sage Publications.

Poffenberger, M. 1990. Joint Management for Forest Lands: Experiences from South Asia. New Delhi: Ford Foundation.

Price, P.G. 1991. Acting in public versus forming a public: conflict processing and political mobilisation in nineteenth century south India. South Asia 14, 91-121.

Rajaram Row, T. 1891. Manual of the Ramnad Samastanam. Madurai: Cleghorn Press (Tamil Nadu State Archives, Madras)

Rajgopalan, n.d. Irrigation Organisations and Irrigation Management: A Case of River-Fed System Tanks Irrigation in Tamil Nadu. Unpublished ms.

Raju, Saradu. 1941. Economic conditions in Madras Presidency I800-I850. Madras: University of Madras.

Reddy, S.T. 1989. Declining groundwater levels in India. Water resources development, Vol. 5, No. 3, pp. $183-90$.

-. 1989. Status of tanks in Karnataka: a study. Prarambha: Bangalore.

Reddy, V.R. Irrigation in colonial India: A Study of Madras Presidency during 186o1900. Economic and Political Weekly, 5-12 May, 1047-54.

Robertson, F. 1984. People and the state: an anthropology of planned development. Cambridge: Cambridge University Press.

Runge, C.F. 1986. Common Property and collective action in economic development. World Development 14, 623-35.

Ruttan, V.W. 1986. Induced institutional innovation. In G.E. Schuh (ed.), Technology, human capital and the world food problem. University of Minnesota, Department of Agriculture and Applied Economics, Miscellaneous Publication-37.

Said, E. 1978. Orientalism. New York: Pantheon Books.

Seabright, P. 1993. Managing local commons: theoretical issues in incentive design. Journal of Economic Perspectives 7, $113-34$. 
Sengupta, N. 1985. Irrigation: traditional vs modern. Economic and Political Weekly $20,1919-38$.

Sengupta, Nirmal. 1991. Managing common property: irrigation in India and the Philippines. New Delhi: Sage Publications.

Shankari, U. and Shah, E. 1993. Water management traditions in India. Madras: PPST Foundation.

Sivanappan, R.K. 1982. Water management in tank irrigation in Tamil Nadu. Workshop on Modernisation of Tank Irrigation: Problems and Issues. Centre for Water Resources, Madras, February 1982.

Spencer, J. 1990. A Sinhala village in a time of trouble: politics and change in rural Sri Lanka. Oxford University Press: New Delhi.

Stein, B. 1980. Peasant state society in medieval south India. Delhi: Oxford University Press.

-. $1^{8} 5$. State formation and economy reconsidered. Modern Asian Studies, 19, $3^{87-}$ 413 .

-. 1989. Thomas Munroe: the origins of the colonial state and his vision of empire. Delhi: Oxford University Press.

Svendsen, M. and Gulati, A. (eds) 1994. Strategic change in Indian irrigation. New Delhi: Indian Council of Agricultural Research, and Washington, D.C.: International Food Policy Research Institute.

Tang, S.Y. 1992. Institutions and collective action: self-governance in irrigation. San Francisco: Institute for Contemporary Studies Press.

Uphoff, N.T. 1986. Local institutional development. West Hartford: Kumarian Press.

Vanberg, V.J. 1994. Rules and choice in economics. London: Routledge.

Vani, M.S. 1992. Role of Panchayat institutions in irrigation management: Law and policy (Tamil nadu and Karnataka). New Delhi: The Indian Law Institute.

Vaidyanathan, A. 1992. Strategy for development of tank irrigation. Madras Institute of Development Studies.

Washbrook, D. 1976. The emergence of provincial politics: the Madras Presidency I87o1920. Cambridge: Cambridge University Press.

-. 1988. Progress and problems: South Asian economic and social history c. 17201860. Modern Asian Studies 22, 57-96.

- 1 1993. The golden age of the Paraiyar? In P. Robb (ed.), Dalit movements and the meaning of labour in India. New Delhi: Oxford University Press.

Wade, Robert. 1987. Village republics: economic conditions for collective action in south India. Cambridge: Cambridge University Press.

Williams, R. 1973. The country and the city. New York: Oxford University Press.

Wood, G. 1985 a. The politics of development policy labelling. Development and Change $16,347-8$.

-. 1985 b. Labelling in development policy: essays in honour of Bernard Schaffer. London: Sage Publications. 